\title{
ハリエンジュによる動的河道内樹林化について STUDY ON THE EXPANSION OF ROBINIA PSEUDO-ACACIA IN GRAVEL-BED RIVER CAUSED BY FLOOD DISTERBANCE
}

\author{
清水義彦 1 小葉竹重機 ${ }^{2} \cdot$ 岡田理志 ${ }^{3}$ \\ Yoshihiko SHIMIZU, Shigeki KOBATAKE and Satoshi OKADA \\ 1正会員 工博 群馬大学助教授 工学部建設工学科（テ365-8515 桐生市天神町1-5-1） \\ 2 正会員 工博 群馬大学教授 工学部建設工学科（テ365-8515 桐生市天神町 $1-5-1$ ) \\ 3 学生会員 群馬大学大学院工学研究科（テ365-8515 桐生市天神町1-5-1）
}

\begin{abstract}
Recently riverine trees in the course of gravel bed-river have extremely increased and enlarged their covered-area over bars and flood plain. Such a situation brings about problems of river management for the environmental aspects as well as the safety of rivers against flood. In order to clarify such problems, we should get the knowledge about how the instream vegetation grows up and expands their covered zones in the gravel-bed river.

In this paper, the cause of the excessive growth of Robinia pseudo-acacia was examined in the segment-1 reach of Watarase River. Especially, from the investigation of the annual rings of tree, it was clear that some forests of Robinia pseudo-acacia in bars were formed right after the main flood. We can consider that the flood caused change of generation of the trees and the damage which the flood gave to the trees can be classified by the scale of the flood external force. Based on the field study and numerical analysis with 2D- flow model, the critical tractive force to be an index of the scale of flood disturbance was evaluated and results showed that rapidly expansion by the germination from fallen trees makes the excessive growth of riverine trees.
\end{abstract}

Key Words : the riverine trees expansion, Robinia pseudo-acacia, gravel-bed river, germination by fallen trees, flood disterbance, $2 D$-numerical flow model

\section{1. はじめに}

近年，河道内植生の著しい繁茂によって樹林化が進み， 河川管理上の䀣案事項となっている箇所が少なくない. 治水面では，主として洪水疎通能力阻害が臨念されるが、 環境面においては，セグメント特有の玉石川原が草本類， 木本類によって占有されて, 河相固有の景観構造の変化 とそこでのハビタートの（潜在自然なものからの）変質 を産んでいる.

河道内樹林化については最近の研究成果では，そのシ ナリオとして, (1)地形変化 (比高差) の出現（2)洪水に よって比高の高、籄所に細粒土砂が堆積一(3)パイオニア 的植生（草本類）の侵入 $\rightarrow$ (4)比高+植生の効果で細粒土 砂堆積が促進(2)よりも効率よく細粒分を捕捉) $\rightarrow$ (5)比高 差の拡大, 木本類の侵入 $\rightarrow(6)$ 冠水頻度の低下と安定した 樹林形成が考えられている[図-1] 1)，2，3，4)。こう した見方は樹林化の素過程として有用であるものの，こ こでは，むしろ冠水すること，洪水擋乱を受けることが 河道内樹林化を持続・拡大させることに着目している ${ }^{5)}$.

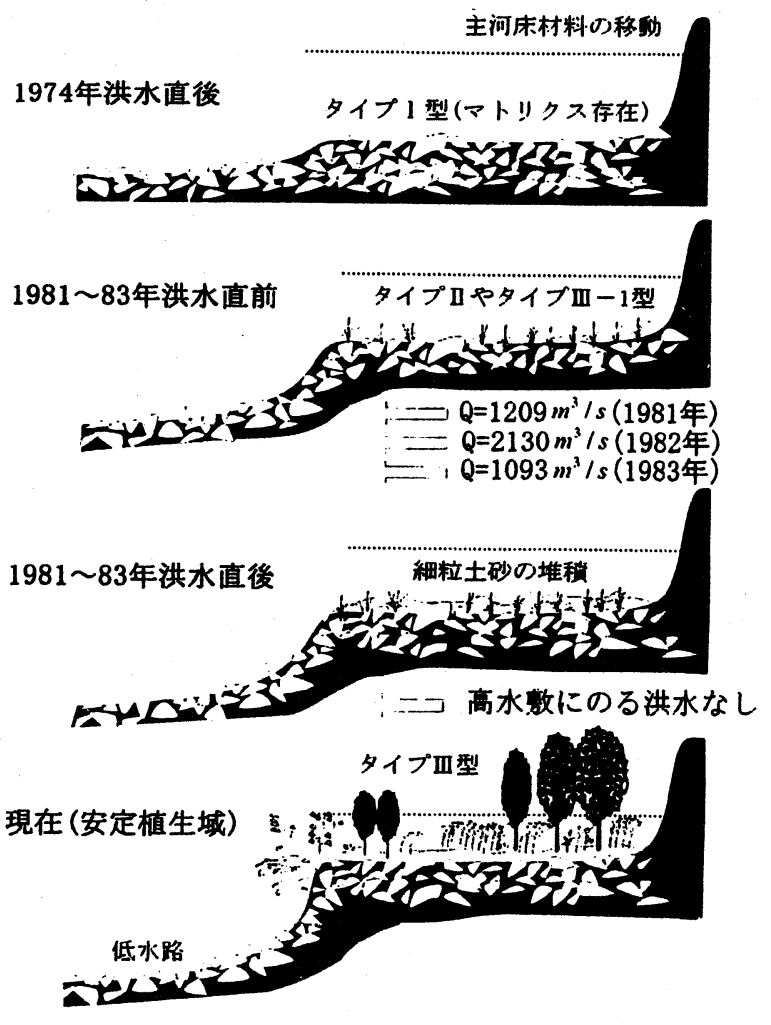

図-1 静的樹林化のシナリオ 
本研究では，セグメント 1 の河相特性をもつ喽床河川 で, ハリエンジュによる樹林化の進んだ中州や高水敷が 豊富に存在する利根川水系渡良瀬川を対象とし5)，そこ での河道内樹林の持続・抎大について，現地調查および 平面流数值解析から検討した.

\section{2. 調査対象河道の概要}

対象とした河道区間は，利根川水系渡良瀬川の利根川 合流点からの $40 \mathrm{~km}$ から $55 \mathrm{~km}$ 付近で, 平均河床勾配 1/140のセグメント 1 に代表される粗い砂床河川である. 近年の河道特性としては河道平面形の変化が顕著ではな く低水路固定と複断面化が進んでいる. 図-2に年最大流 量の経年変化を示す.ここでの対象区間では計画流量 $3500 \mathrm{~m}^{3} / \mathrm{s}$ ，低水路満杯流量が現況で約 $1000 \mathrm{~m}^{3} / \mathrm{s}$ である. ここでは, 近年, 中州・高水敷がハリエンジュの樹林化 によって占有される傾向にある. 図-3は調查した州の一 つで，樹林化の経年的な進行を示した（期間 $1:$ S46,期 間 $2: S 58$,期間 $3: \mathrm{H7}$ ）。樹林化の詳細については文 献6に述べているので参照されたい.

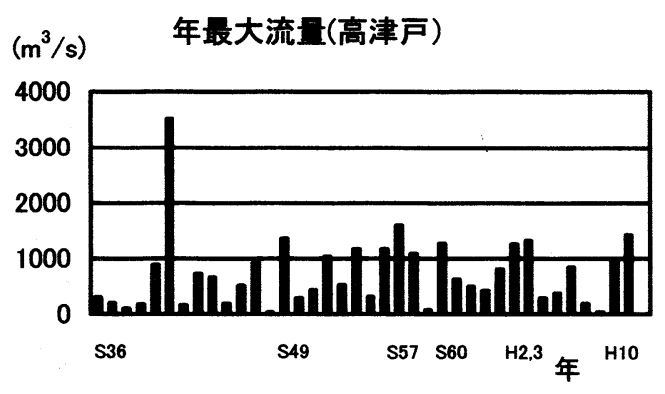

図-2 年最大流量の時系列

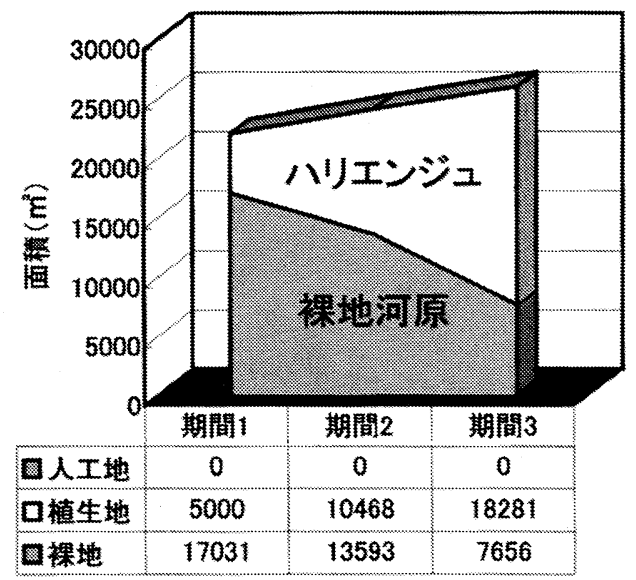

図-3 調查区間内の州の樹林化

\section{3. 既往洪水と中州樹木の世代交代}

写真-1は注目したハリエンジュの樹林化中州 $(52 \mathrm{~km}$ 付近）である. ここでの樹齢調査を行った結果，ほとん どが年輪 16 年であった [図-4] .

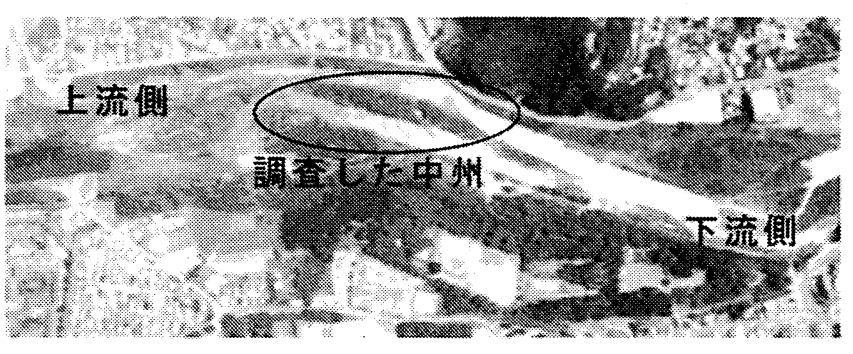

写真-1 年輪調查したハリエンジュ樹林ともつ中州

これは，昭和 57 年洪水（流量 $1596 \mathrm{~m}^{3} / \mathrm{s}$ で，ここでの計 画流量は $3500 \mathrm{~m}^{3} / \mathrm{s}$ ) 直後にほとんどのハリエンジュが 生まれたことを意味する. ところで，昭和56年に撮られ た航空写真によれば, この時点で同中州にはかなりの樹 木がすでに繁茂していた事実が認められた. したがって, ハリエンジュは昭和57年洪水での擋乱によって世代交代 し，57年洪水後からの新たな再生過程を経て現況の樹林 地を形成したものであることが分かる. そこで，57年洪 水が中州上の樹木に与えた擋乱を, 洪水規模を指標とし て見ることにした.
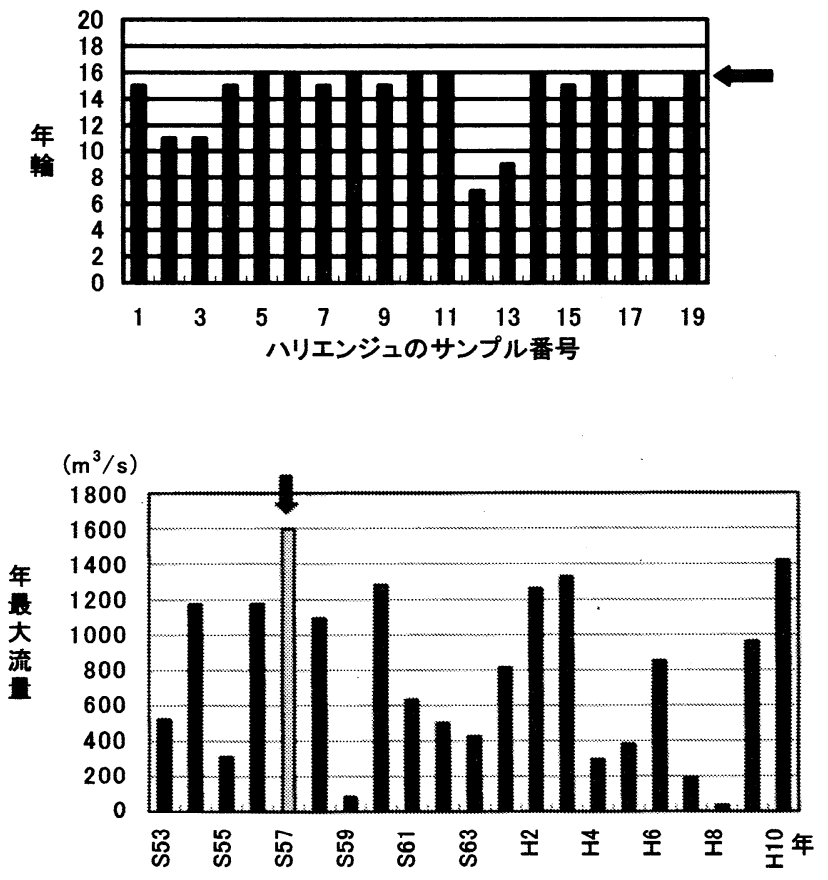

，図-4 中州の年輪調査と既往洪水との関係

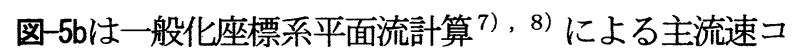
ンターで着目した中州では $4.0 \mathrm{~m} \sim 5.0 \mathrm{~m} / \mathrm{s}$ 程度である （ただし，以下の計算では樹木による流速低減効果は考 慮していない）。州上の樹木一の洪水ストレスは，木そ 


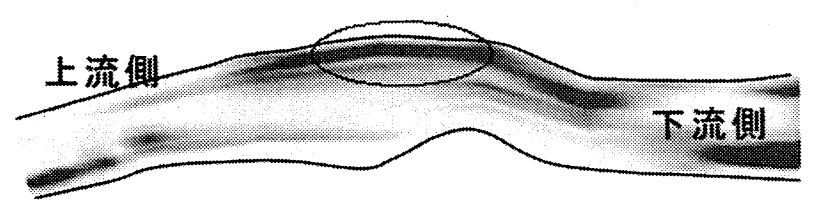

図-5a＼cjkstart昭和57年洪水の再現計算 [水深 $\mathrm{m}$ ]

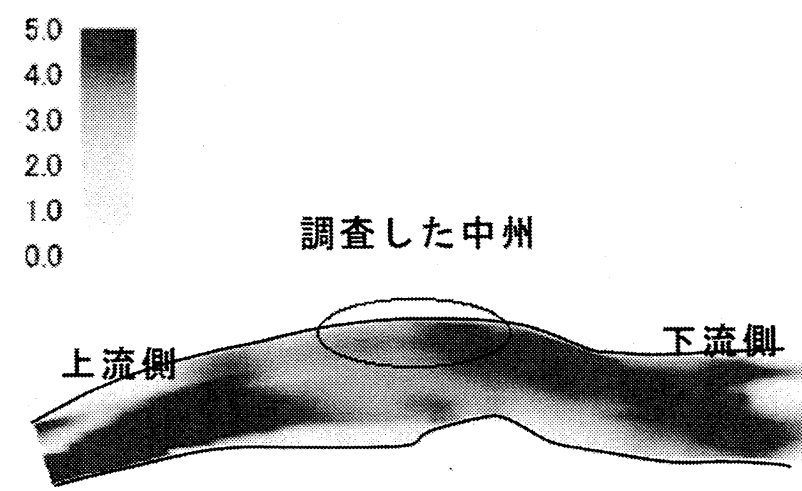

図-5b＼cjkstart昭和57年洪水の再現計算 $[$ 主流速 $\mathrm{m} / \mathrm{s}]$

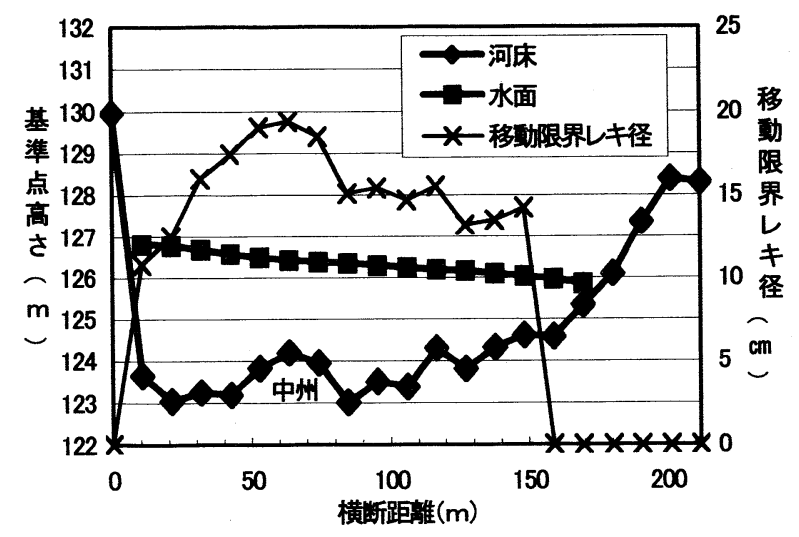

困-6 調直した中州の移動限界磻径

のものにかかる流体力もさることながら河床材料の移動 による摚乱が大きく影響する. 瀬崎ら ${ }^{9)}$ は草本類の流失 機構を河床材料の移動に着眼して現地調査から有用な知 見を見出しており，木本類においても，とくに，ハリエ ンジュはその主根茎は浅く，表層河床材料のどの粒径の ものが動くかで樹林に与える破壊規模（洪水ストレス (洪水が樹木に与えた影響を洪水ストレスと呼ぶことに する）で，これを(1)流失，(2)完全倒木（根茎の完全な切 断），(3)根付倒木・傾斜倒木（根茎の碟床内での残存) に分類する）が，移動限界礫径を指標として区別できる と考える. 図一6は中州代表断面での移動限界磷径の推定

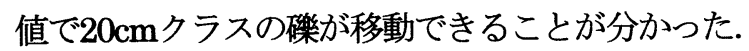

\section{H10.9洪水後の中州樹林地の再生}

さて，平成10年 9 月にも昭和 57 年洪水とほぼ規模の等し い洪水（流量 $1420 \mathrm{~m}^{3} / \mathrm{s}$ ）を渡良瀬川は経験した. 上記 の中州とは異なる中州 $(43.6 \mathrm{~km}$ 地点で, 同じセグメン ト 1 内の樹林化の顕著なもの）で洪水前後の現地観測を 行い, H10.9洪水での樹木の流失や倒木が顕著であるこ とが認められた [写真-2]．ここでも同様な数值計算か ら移動限界碩径を推定すると $15-20 \mathrm{~cm}$ 程度で〔図-7〕， これは州の表層の $60 \%-90 \%$ 粒径に相当する [図-8］. よって, 異なる地点の中州ではあるが, H10.9洪水も S57洪水が与えた中州の洪水擋乱や中州樹木一の洪水ス トレスはほぼ同程度のものと判断できる.

そこで, H10.9洪水が与えた州の樹木の破壊, 再生を 現地調査から求めた. 図-9は調查した州の平面スケッチ で, A,B,D は八リエンジュ樹林，C は硯河原に草本類 が存在し，一部にハリエンジュの林が見られる. 中州で サンプル空間として $10 \mathrm{~m} \times 20 \mathrm{~m}$ 格子を設定し密生度を評 価した（表-1）。ここで密生度は, 洪水後に残った樹木 について樹林地内空間における遮蔽面積で評価した. 洪 水痕跡から見ると中州水際での擋乱が大きく樹木の流失 も推定された. その他では上記(3)の洪水ストレスが顕著 で, 写真-3のように樹木が傾斜しながら,その上を硆の堆 積している状況（傾斜倒木）が洪水摚乱の大きい簀所の 特徴として見出された. 表-2に各地点の倒木 - 傾斜倒木 率を示す.
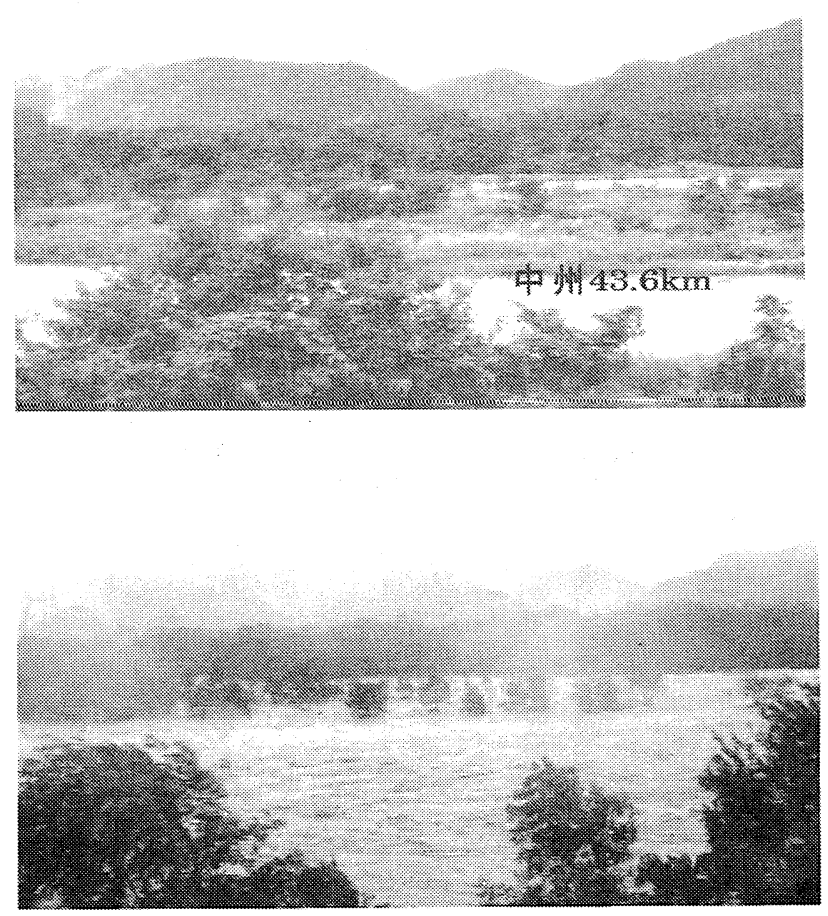

写真-2 観測地の中州とH10洪水時（916）の状況 


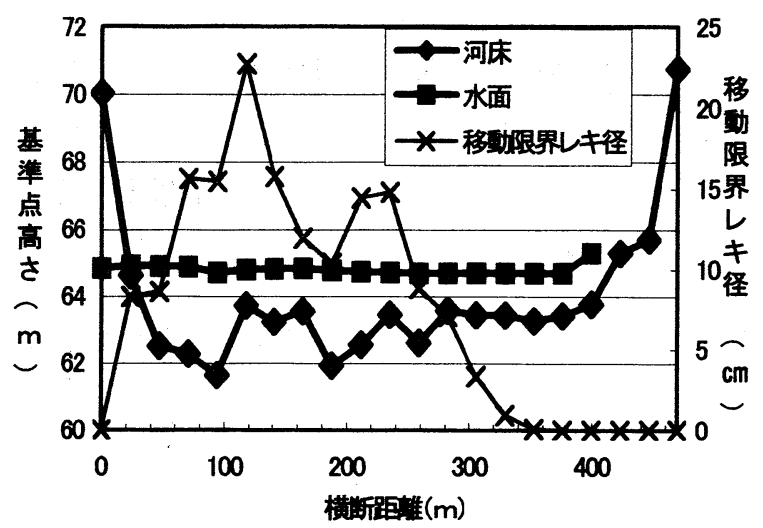

図-7 推定した移動限界磷径

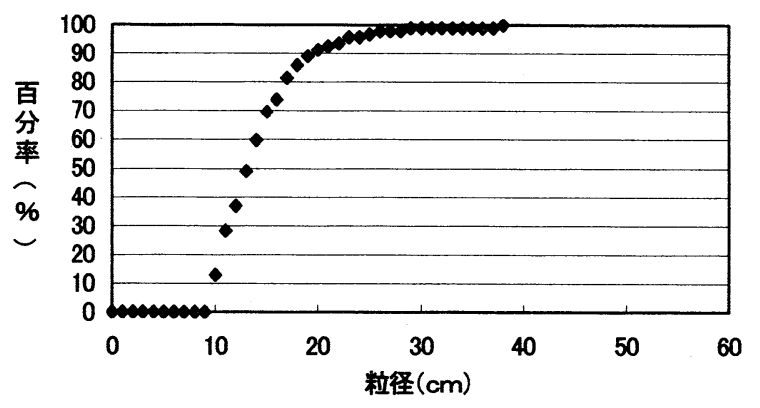

図-8 州表層の磷の粒度分布 [径 $10 \mathrm{~cm}$ 以上]

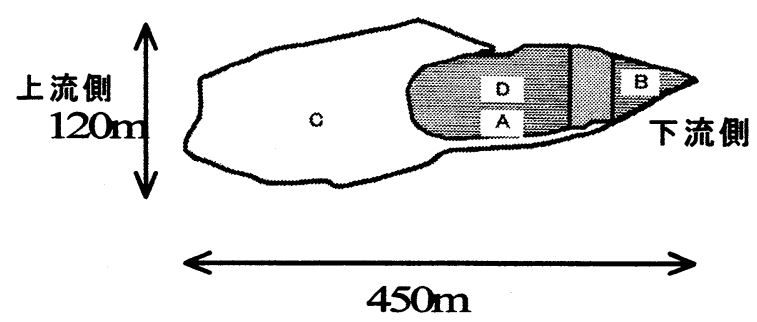

図-9＼cjkstart調查した中州の平面形 $(43.6 \mathrm{~km})$

表-1 中州の各地点での樹木密生度

\begin{tabular}{|l|l|}
\hline 地点 & 密生度 $[1 / \mathrm{m}]$ \\
\hline $\mathrm{A}$ & 0.00880 \\
\hline $\mathrm{B}$ & 0.0152 \\
\hline $\mathrm{C}$ & 0.00347 \\
\hline $\mathrm{D}$ & 0.0104 \\
\hline
\end{tabular}

表-2 中州の各地点での倒木, 傾斜倒木率

\begin{tabular}{|l|l|}
\hline 地点 & 倒木 ・傾斜倒木率 $[\%]$ \\
\hline $\mathrm{A}$ & 47.826 \\
\hline $\mathrm{B}$ & 0 \\
\hline $\mathrm{C}$ & 66.667 \\
\hline $\mathrm{D}$ & 14.286 \\
\hline
\end{tabular}

また, H10洪水 1 年後の同中州での調査（H11.11月実 施）で, ハリエンジュの倒木, 傾斜倒木のほとんどから 萌芽して急激な密生度増加が起こっていることが認めら れた. 写真-4は倒木 1 本からの萌芽の様子である. 八リ エンジュはとくに正の屈光性が強く幹からの萌芽が著し い. H10洪水 2 年後の同中州での調查 (H12.7月実施) では, 出水一年後に急激に増加した萌芽本数が，成長に 伴い自然に淘汰されて減少していることが確認された. 图-10に出水 1 年後と 2 年後の倒木からの萌芽本数を示 した. これは出水 1 年後, 全長 $6 \mathrm{~m}$ の一本の倒木から 1 5 本程度萌芽し, 出水 2 年後には, それが淘汰されて 7 本程度に減少したことを表している. この 1 年間での淘 汰率は平均して54\%程度であった。
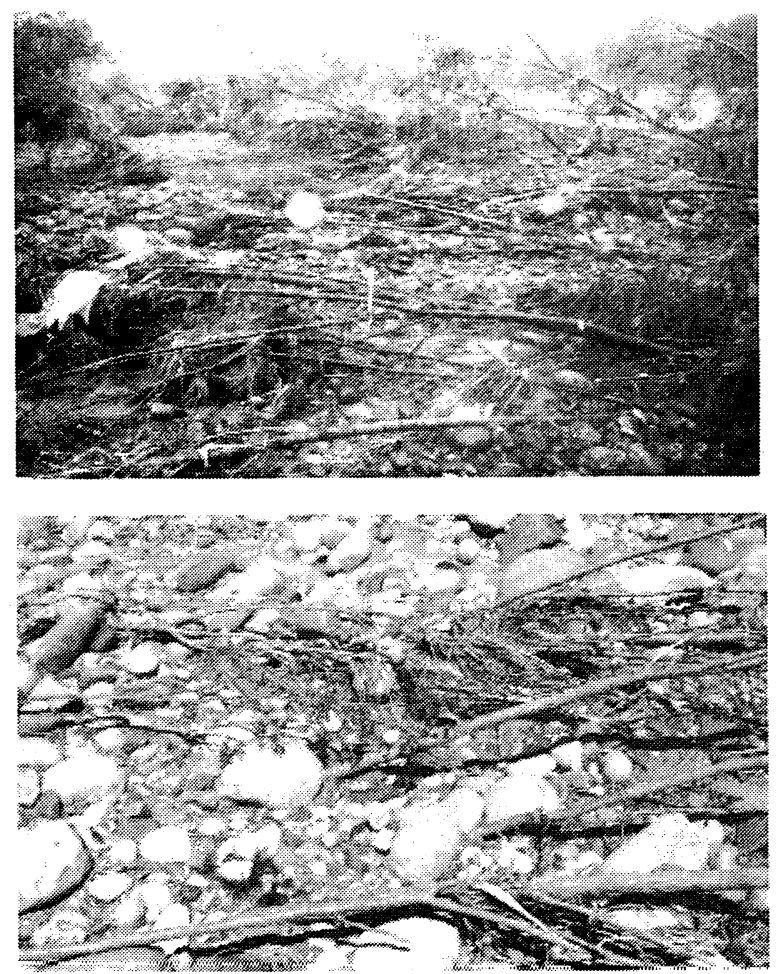

写真-3 中州で倒木したハリエンジュ林

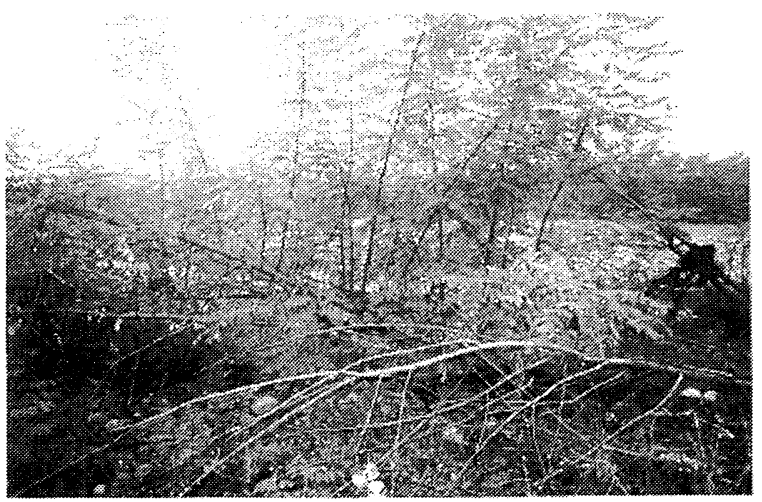

写真-4 倒木 1 本から萌芽したハリエンジュ 


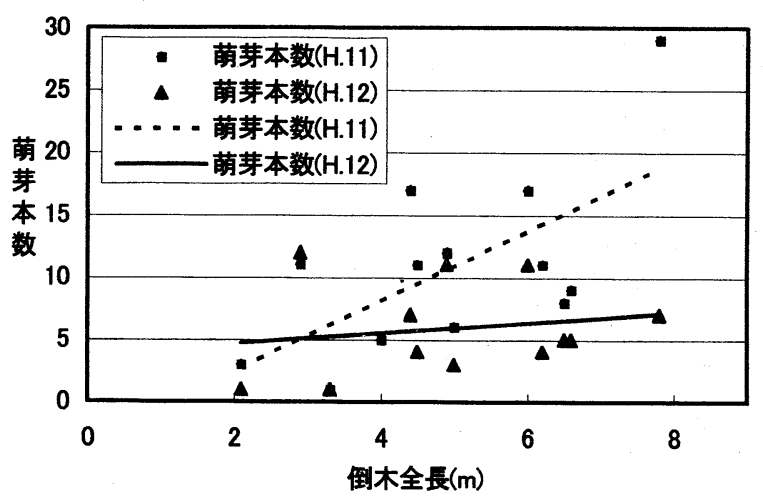

図-10 倒木からの萌芽本数（倒木 1 本あたり）

さらに，図-11は倒木した同一のハリエンジュについて， 根元からの幹長さを $50 \mathrm{~cm}$ ごとに区分し，萌芽本数と平 均樹高の分布を出水 1 年後と 2 年後で比較したものであ る. この図から, 出水 1 年後には平均高さ $2 \mathrm{~m} \sim 3 \mathrm{~m}$ 程度 の林がすでに形成されることが分かる. また 2 年後には, 萌芽本数は减少するものの, 根元に近い部分で急激な成 長が見られ，その高さは4.5mに達する．［写真-5]
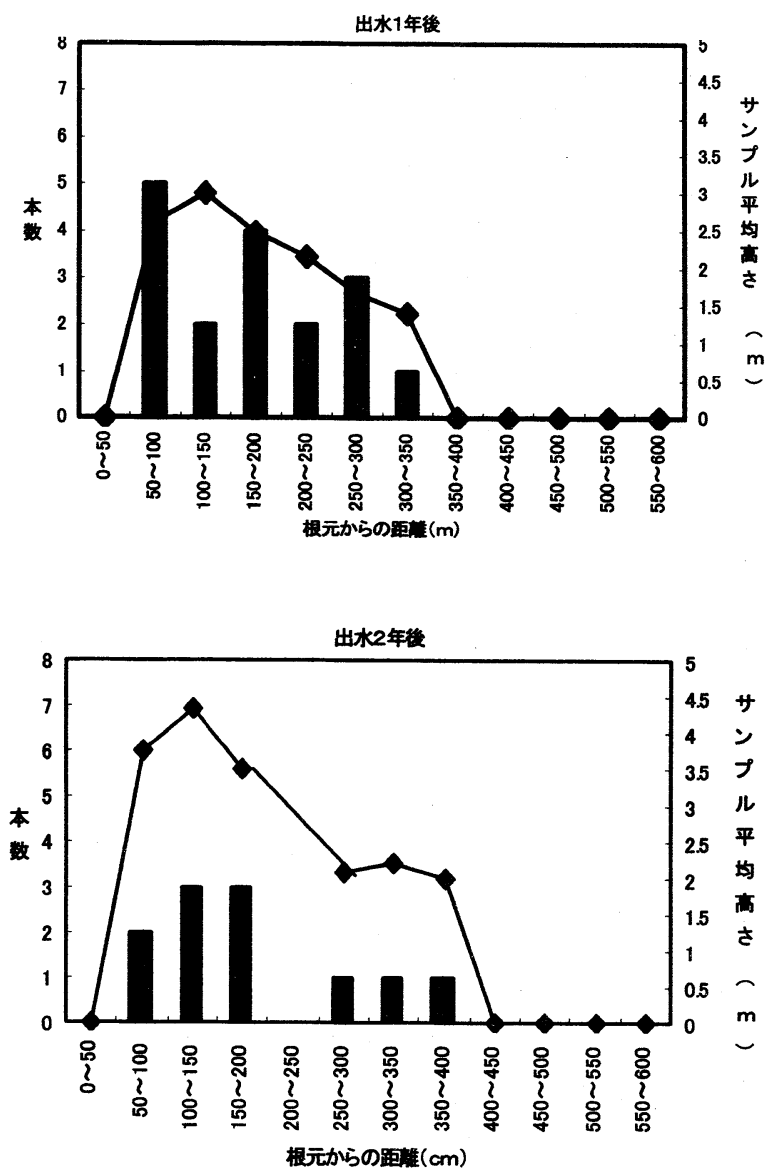

図-11 幹根元からの萌芽本数、平均樹高の比較

図-12は倒木1本あたりの萌芽本数に対する, 出水 1 年後 と 2 年後の根元幹径の比で評価した年成長率を表したも
ので, 萌芽本数の多い倒木は萌芽の成長が悪いが, 萌芽 本数の少ない倒木は萌芽の成長が良く, その成長率は5 倍以上に達することがわかる. また，図-13は成長率の 分布を示したもので, ほとんどの萌芽が1年間で1倍〜 3 倍程度成長していることがわかる.

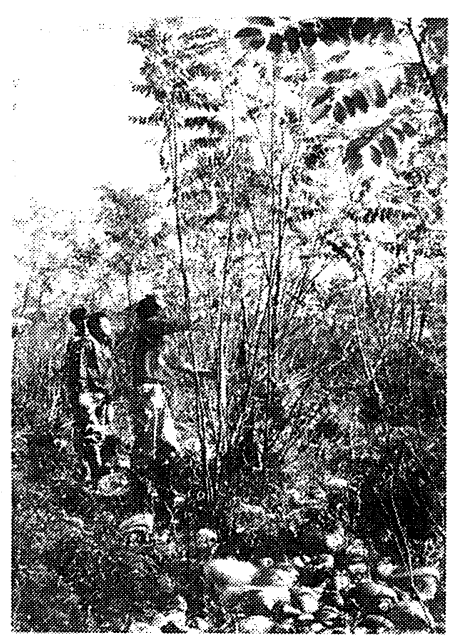

写真-5 倒木から成長したハリエンジュの萌芽

(出水 1 年後)

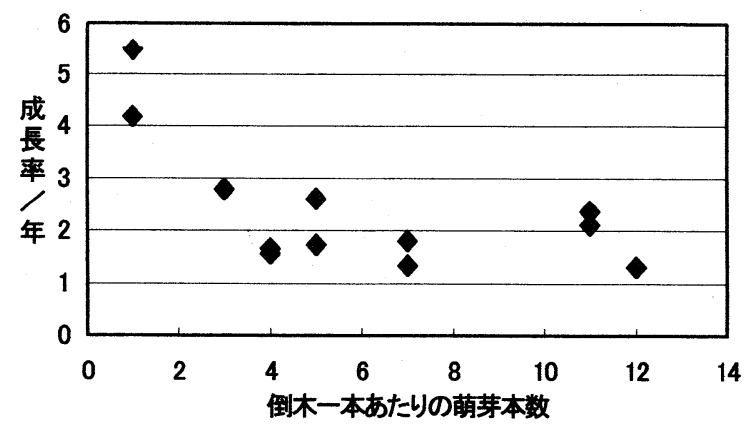

図-12 倒木 1 本あたりの萌芽本数に対する成長率

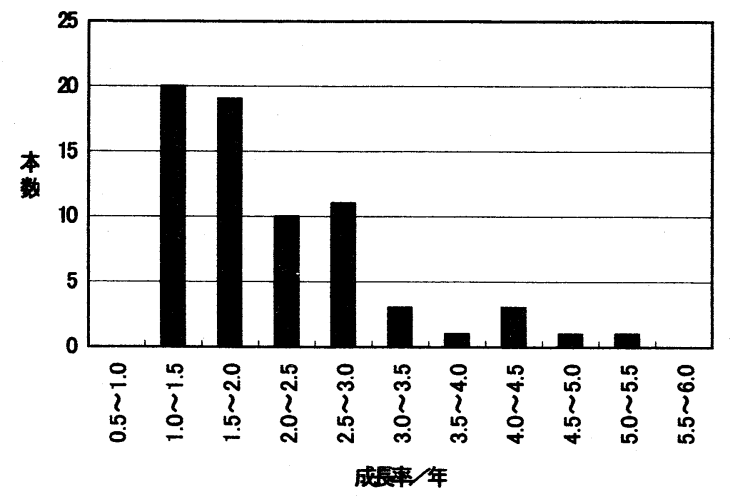

図-13 成長率の分布

以上より，洪水擋乱を受けた中州上のハリエンジュは， $\mathrm{H} 10$ 洪水後 1 年目には急激な萌芽により本数が増加し, 2 年目には自然淘汰されその本数は减少するものの, 萌芽 の急激な成長により樹林化が促進されることがわかる. すなわち洪水擋乱はその規模によっては，その後の急激 
な樹林化を促すことが予想される．図-14に，中州上の ハリエンジュ本数の変化を表した. H10洪水後 1 年目に して洪水前の本数の10倍に達し，2年目には減少するも ののその本数は洪水前の5倍である. この図からも樹林 化が促進していることが見受けられる. 先述した昭和57 年洪水によって $52 \mathrm{~km}$ 地点の中州も同じプロセスで樹林 化した事が推測できる.

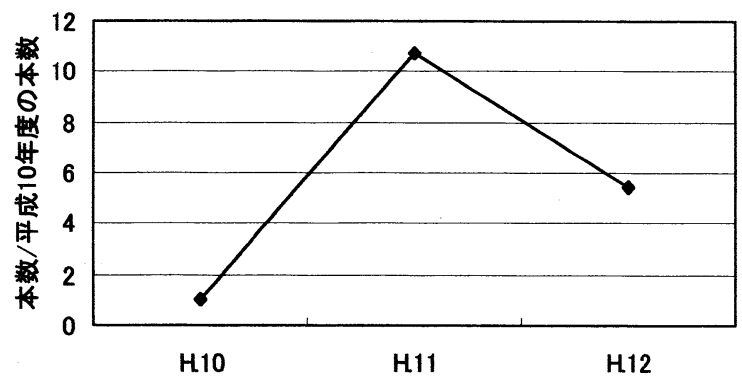

図-14 中州上のハリエンジュ本数の変化

\section{5. 動的樹林化と静的樹林化}

以上の検討から䂺床河川の河道内樹林化についての 幾つかの疑問に答えることができそうである.すなわち，

・ なぜ，砂床河川で樹林化が顕著なのか?

・なぜ, 河道内で林がすみやかに形成されるのか? である.

まず，最近の礫床河川の河道特性（低水路固定と複 断面化）や洪水規模から見ても樹林地を完全にフラッ シュさせるようなことはなかなか起こらない，しかも， セグメント 1 河川のように碩床では，河床材料の大規模 な移動を起こすような擋乱は容易ではない. これからす ると，栄養繁殖できるハリエンジュ，ヤナギ類などは碟 床に根茎が存在する限り再生できる. この意味から碩床 と栄養繁殖できる木本類が樹林化を産むキーポイントと なっている. とくに，ハリエンジュは磷材料に絡まる形 で根茎の平面的広がりをもつことから，近年の洪水擋乱 から受けるストレスは写真-3 に示すように，大きくとも 根付倒木や傾斜倒木が生じる程度である.

洪水擋乱後のハリエンジュが倒木や傾斜倒木となる 環境ではきわめて近い将来，より著しい繁茂となる樹林 地を形成することが予想される．もちろん，比高差の拡 大・冠水頻度の低下から生まれる樹林化（静的樹林化と 言うべきもの）も多くの磷床河川で健在化しているが, ここで議論した洪水擋乱による,言わば動的樹林化では 洪水摚乱後の速やかな再生がその特徵である.

渡良瀬川の観測区間では，ハリエンジュの倒木群に よる河畔林が形成されている箇所がある（写真-6）。年 輪調查から 16 年が読み取れ，これも昭和 57 年洪水直 後にハリエンジュが一斉に発芽したことを意味している. すなわち, 自然河畔林が形成される一つの理由も動的樹
林化にあると考えられる. より多くの事例とともに樹林 地回復過程の現地調查を行い検討して行きたい.

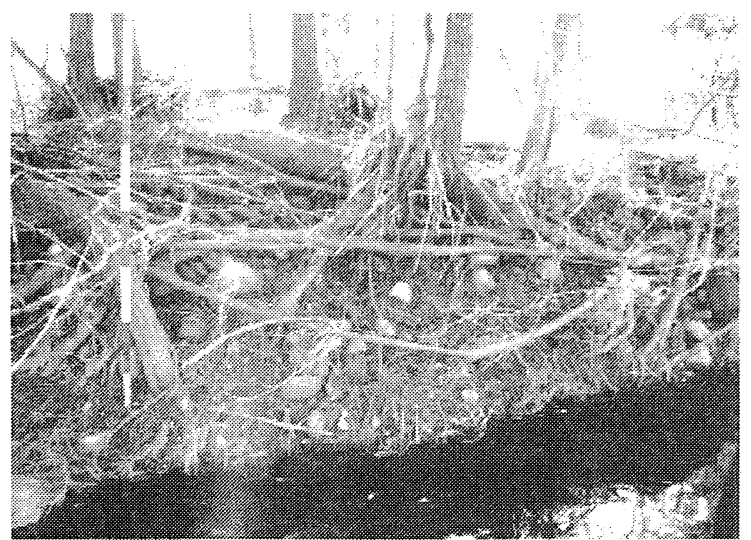

写真-6 ハリエンジュの倒木による河畔林の形成

謝辞 : 本研究を進めるにあたり，建設省渡良瀬川工事事 務所の協力を得た。また，本研究は（財）河川環境管理 財団の河川整備基金助成事業を受けた．記して謝意を表 します。

\section{参考文献}

1）李参熙・藤田光一・塚原隆夫 ・渡辺敏・山本晃一・望月達 也 : 磷床河川の樹林化に果たす洪水と細粒土砂流送の役割, 水工学論文集, 42 巻, pp.433-438,1998.

2) 藤田光一・渡辺敏・李参熙・塚原隆夫 : 礫床河川の植生繁茂 に及ぼす土砂堆積作用の重要度, 第4回河道の水理と河川環 境に関するシンポジウム論文集（新しい河川整備・管理の理 念とそれを支援する河川技術に関するシンポジウム）， pp.117-122,1998.

3）清水義彦，小葉竹重機，新船隆行，岡田理志 : 磷床河川の河 道内樹林化に関する一考察，第43巻，pp. 971-976, 1999.

4）李参熙・山本晃一・望月達也・藤田光一・塚原隆夫・渡辺 敏 : 扇状地磷床河道における安定植生域の形成機構に関する 研究，土木研究所資料第3266号，168p，1999.

5) 清水義彦, 小葉竹重機, 岡田理志, 新船隆行, 岩崎工 : 洪水 擋乱によるハリエンジュの破壊・再生と河道内樹林化につい て，河川技術に関する論文集，第6巻，59-64，2000.

6) 河道変遷研究会 : 河道変遷特性に関する研究，(財) 河川環境 管理財団，pp. 124-137, 1999.

7) 長田信寿, 細田尚, 村本芳雄 : 河岸侵食を伴う河道変動の特 性とその数值解析法に関する研究，土木学会論文集， No. $621 /$ II-47 pp. 23-39, 1999.

8）長田信寿 : 一般化座標系を用いた平面 2 次元非定常流れの数 值解析，水工学における計算機利用の講習会講義集，土木学 会水理委員会基礎水理部会，61-76，1999.

9）瀬崎智之・服部敦・近藤和仁・藤田光一・吉田昌樹 : 砂州上 草本植生の流失機構に関する現地観測と考察，水工学論文集， 44巻, pp.825-830,2000.

（2000. 10. 2受付） 